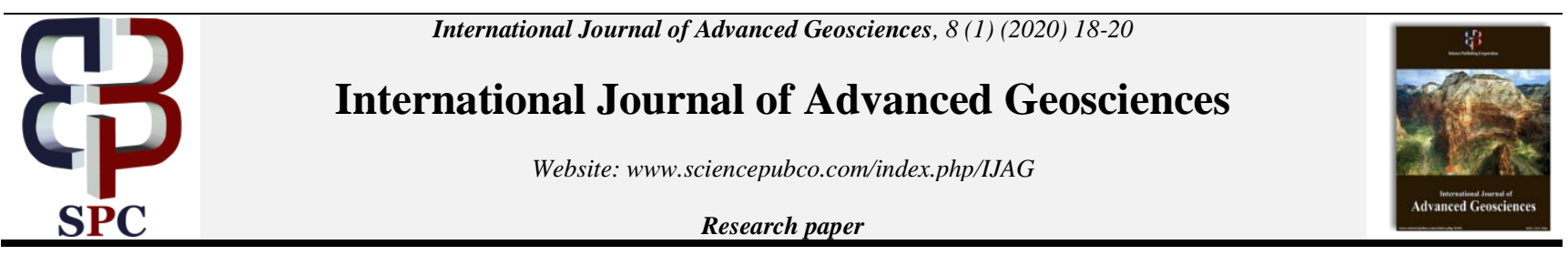

\title{
Fertilizer doses for jute cultivation after onion harvest
}

\author{
Manika Rani Debnath ${ }^{1 *}$, Md. Mahabubul Islam², Md. Ayub Khan², Sharmin Akter ${ }^{1}$, \\ Md. Mukul Mia ${ }^{1}$, Protap Narayan Nandi ${ }^{3}$ \\ ${ }^{1}$ Scientific Officer, Bangladesh Jute Research Institute \\ ${ }^{2}$ Chief Scientific Officer, Bangladesh Jute Research Institute \\ ${ }^{3}$ Former Consultant, International Rice Research Institute \\ *Corresponding author E-mail: manika00474@yahoo.com
}

\begin{abstract}
An experiment was conducted to evaluate the fertilizer dose for jute cultivation at the field after harvesting of onion at Gangabordi and Talma, Faridpur during 2017 with five treatments with different level of Urea, Triple Super Phosphate, Muriate of Potash and Gypsum. The result revealed that the treatment of higher doses of fertilizer gave the statistically significant highest fibre (2.76t/ha) yield whereas treatment of lower doses of fertilizer gave the lowest fibre yield $(2.40 \mathrm{t} / \mathrm{ha})$ but the Benefit Cost ratio from different treatment showed statistical non significance. From the view of economic profitability, farmers may use no fertilizer at their field during jute cultivation where previous crop was onion.
\end{abstract}

Keywords:BCR; Fertilizer Dose; Jute; Onion; Yield.

\section{Introduction}

Faridpur is mostly a riverine area of the country belongs to Active Ganges River Floodplain (AEZ-10), Low Ganges River Floodplain (AEZ-12), Gopalganj-Khulna Bills (AEZ-14) and Old Meghna Estuarine Floodplain (AEZ-19) (FAO, 1988). Most of the soils of this region are formed from the river deposits. As a result of sedimentations, soils of this region are very fertile and diversified crops can be grown there during the rainy season as well as in winter. This region is well known for good quality onion and jute fibre production. About 1,53,251 ton onion was produced from 46,400 acre and 1,31,338 ton jute was produced from 1,81,927 acre during 2010-11at Faridpur (District Statistics, 2013). Mostafizur et al., 2017 identified 36 jute based cropping pattern at Faridpur region which covered 43.49\% of Net Cropped Area of that region. The Onion - Jute -Fallow covered about 25,960 hectare land in Faridpur region during 2014-15. It is known that a huge amount of fertilizer is used for onion production. But the residual effect of the used fertilizer is unknown. Excess use of fertilizer can hamper the growth of crop through its toxic effects and can deteriorate the water quality. It is reported by Ju et al. (2006) and Hvishtendahl (2010) that redundant water and fertilizers can cause serious environmental problems, such as greenhouse gas emission, soil degradation, freshwater contamination, and natural resource consumption. The use of unwanted fertilizer during jute production at post harvest onion field may cause financial losses to the farmer, on the other hand less fertilizer use may hamper jute yield. Farmers fall in dilemma about the required dose of fertilizer for jute production at onion field as optimum dose of fertilizer is always essential for desired yield of jute fibre. This problem is also faced by the farmers of different regions in Bangladesh as Nasim et al. (2017) reported that Onion - Jute - Fallow cropping pattern covers 54, 184 hectare land covering 39 districts and Onion Jute - Fallow covers 45,200 hectare land covering 29 districts of Bangladesh. Hence, this experiment was undertaken to determine the fertilizer doses for the production of jute at post harvest onion field.

\section{Materials and methods}

\subsection{Location}

The experiment was conducted at Faridpur, Bangladesh which is located at $23^{\circ} 36^{\prime} 22^{\prime \prime} \mathrm{N}$ and $89.50^{\prime} 26^{\prime \prime} \mathrm{E}$ and $15 \mathrm{~m}$ from the sea level. It was trailed at 03 farmer's field located at Gangabordi, Faridpur and Talma, Faridpur during April, 2017. The initial soil status was given at Table 1.

Table 1: Nutrient Status of the Initial Soil

\begin{tabular}{ll}
\hline Properties & Amount \\
\hline $\mathrm{pH}$ & 7.6 \\
Nitrogen $(\%)$ & 0.12 \\
Phosphorus $(\mathrm{ppm})$ & 21.15 \\
Potassium $(\mathrm{ppm})$ & 0.35 \\
\hline
\end{tabular}

Copyright @Manika Rani Debnath et al. This is an open access article distributed under the Creative Commons Attribution License, which permits unrestricted use, distribution, and reproduction in any medium, provided the original work is properly cited. 


$\begin{array}{lc}\text { Sulphur }(\mathrm{ppm}) & 5.7 \\ \text { Zinc (ppm) } & 0.675 \\ \text { Boron } & 0.38\end{array}$

\subsection{Design of the experiment}

The experiment was laid out in randomized complete block design with five treatments (Table 2) which were replicated at three times. Recommended production practices were followed except fertilizer dose. Unit plot size was 3 x $1 \mathrm{~m}$ with $1 \mathrm{~m}$ distance from plot to plot. Spacing between the plots and around the field was $1 \mathrm{~m}$. Depth of the drain was maintained as $80 \mathrm{~cm}$ up to the harvest of the crop.

\subsection{Treatments}

Five treatment combinations were used related to Urea, TSP, MoP and Gypsum (Table2).

Table2: Treatment Combination of Urea, TSP, Mop and Gypsum

\begin{tabular}{|c|c|c|c|c|}
\hline Treatments & Urea (Kg/ha) & $\mathrm{TSP}(\mathrm{Kg} / \mathrm{ha})$ & $\mathrm{MoP}(\mathrm{Kg} / \mathrm{ha})$ & Gypsum (Kg/ha) \\
\hline $\mathrm{T}_{1 \text { (No fertilizer) }}$ & 00 & 00 & 00 & 00 \\
\hline $\mathrm{T}_{2(25 \% \text { of } \mathrm{RDF})}$ & 50 & 12.5 & 15 & 23.75 \\
\hline $\mathrm{T}_{3(50 \% \text { of } \mathrm{RDF})}$ & 100 & 25 & 30 & 47.5 \\
\hline $\mathrm{T}_{4(75 \% \text { of } \mathrm{RDF})}$ & 150 & 37.5 & 45 & 71.25 \\
\hline $\mathrm{T}_{5(\mathrm{RDF})}$ & 200 & 50 & 60 & 95 \\
\hline
\end{tabular}

$\mathrm{RDF}=$ Recommended Dose of Fertilizer for Jute.

\subsection{Procedure}

Half of Urea and total amount of TSP, MoP and Gypsum were incorporated to the experimental plots as per design during final land preparation. Remaining half of Urea was top dressed at time of 45 days after sowing. The name of the jute variety was O-9897. A sample of 10 plants was collected from each replication and then plant height and base diameter was recorded. Plant population was counted just before harvest. Jute plants were harvested at 120 days age during August, 2017. Then fiber and stick yields were recorded after retting and drying of the fibre and stick of the whole plot. The mean differences among the treatments were adjusted as per Duncan Multiple Rang Test (DMRT) (Gomez and Gomez, 1984) with the help of SPSS 14.0. Initial soil nutrient status (Average) of the experimental plots was presented at Table 1 and yield attributes results were shown at Table 3. Economic analysis (Table 4) was done by considering the market value of inputs (Molla et al., 2015) assuming Urea, TSP, MoP and Gypsum as 16, 22, 15 and 10 Taka/Kg respectively and output (fibre as 50 $\mathrm{Taka} / \mathrm{Kg}$ and stick as $2 \mathrm{Taka} / \mathrm{Kg})$.

\section{Results and discussions}

\subsection{Yield analysis}

Plant height was significantly influenced by different fertilizer doses which ultimately contributed the statistically significant fibre and stick yield. The other yield contributing characters namely plant population, base diameter and bark thickness were changed with different fertilizer doses but those were not statistically significant.

The tallest jute plants $(3.42 \mathrm{~m})$ were found at $\mathrm{T}_{5}$ which was statistically identical with other treatments except $\mathrm{T}_{1}(3.04 \mathrm{~m}) . \mathrm{Khanom}$ et al., 2012 reported the highest plant height as $3.03 \mathrm{~m}$ at different fertilizer doses on the white jute variety BJC-2197. Gani et al. found the highest plant height of jute from different fertilizer doses as very near to $3.5 \mathrm{~m}$ during 2018 .

The result also explored that the highest plant population $\left(42.53 \mathrm{plant} / \mathrm{m}^{2}\right)$, base diameter $(15.08 \mathrm{~mm})$ and bark thickness $(1.53 \mathrm{~mm})$ were observed at $\mathrm{T}_{5}$ where as the lowest values were observed at $\mathrm{T}_{1}$ at all these three parameter but the differences were not statistically significant.

The highest fibre (2.76 t/ha) yield was obtained from $\mathrm{T}_{5}$ which was statistically identical with $\mathrm{T}_{2}, \mathrm{~T}_{3}$ and $\mathrm{T}_{4}$. This result was corroborated by Ali et al., 2017 and Gani et al., 2018. The lowest fibre yield was recorded at $\mathrm{T}_{1}(2.40 \mathrm{t} / \mathrm{ha})$. Islam and Silva (2011) estimated average yield of jute was $2.21 \mathrm{t} / \mathrm{ha}$ at Faridpur region.

The highest stick yield (5.20 t/ha) was recorded for $T_{5}$ and lowest ( $\left.4.58 \mathrm{t} / \mathrm{ha}\right)$ for $\mathrm{T}_{1}$ treatment. The plant height, fibre yield of $\mathrm{T}_{2}, \mathrm{~T}_{3}$ and $\mathrm{T}_{4}$ was statistically identical. The stick yield of $\mathrm{T}_{2}$ and $\mathrm{T}_{3}$ was statistically identical.

Table 3: Yield and Yield Contributing Character of Jute from Different Doses of Fertilizer

\begin{tabular}{|c|c|c|c|c|c|c|}
\hline Treatments & $\mathrm{PP}\left(\mathrm{No} . / \mathrm{m}^{2}\right)$ & $\mathrm{PH}(\mathrm{m})$ & $\mathrm{BD}(\mathrm{mm})$ & BT (mm) & $\mathrm{FY}(\mathrm{t} / \mathrm{ha})$ & SY (t/ha) \\
\hline $\mathrm{T}_{1}$ & 40.60 & $3.04 \mathrm{~b}$ & 13.40 & 1.40 & $2.40 \mathrm{~b}$ & $4.58 \mathrm{c}$ \\
\hline $\mathrm{T}_{2}$ & 41.15 & $3.07 \mathrm{ab}$ & 13.53 & 1.42 & $2.54 \mathrm{ab}$ & $4.71 \mathrm{bc}$ \\
\hline $\mathrm{T}_{3}$ & 41.63 & $3.07 \mathrm{ab}$ & 14.21 & 1.47 & $2.56 \mathrm{ab}$ & $4.74 \mathrm{bc}$ \\
\hline $\mathrm{T}_{5}$ & 42.53 & $3.42 \mathrm{a}$ & 15.08 & 1.53 & $2.76 \mathrm{a}$ & $5.20 \mathrm{a}$ \\
\hline $\mathrm{CV}(\%)$ & 6.2 & 6.91 & 7.87 & 15 & 7.00 & 4.78 \\
\hline Level of Significance & NS & $5 \%$ & NS & NS & $5 \%$ & $5 \%$ \\
\hline
\end{tabular}

$\mathrm{PP}=$ Plant Population, $\mathrm{PH}=$ Plant height, $\mathrm{BD}=$ Base diameter, BT= Bark Thickness,FY= Fibre Yield,SY $=$ Stick Yield CV $=$ Coefficient of variance.

\subsection{Economic analysis}


Table 4: Economic Analysis of Jute from Different Doses of Fertilizer

\begin{tabular}{llll}
\multicolumn{2}{c}{ Table 4: Economic Analysis of Jute from Different Doses of Fertilizer } & BCR \\
\hline Treatments & Input Cost (Taka/ha) & Output Cost (Taka/ha) & 2.24 \\
$\mathrm{~T}_{1}$ & 57473 & $129261 \mathrm{~b}$ & 2.31 \\
$\mathrm{~T}_{2}$ & 59010.5 & $136476 \mathrm{ab}$ & 2.27 \\
$\mathrm{~T}_{3}$ & 60548 & $137537 \mathrm{ab}$ & 2.23 \\
$\mathrm{~T}_{4}$ & 62085.5 & $138551 \mathrm{ab}$ & 2.33 \\
$\mathrm{~T}_{5}$ & 63623 & $148421 \mathrm{a}$ & 6.53 \\
$\mathrm{CV}(\%)$ & - & 6.76 & $\mathrm{NS}$ \\
Level of Significance & 5 & 5 & \\
\hline
\end{tabular}

The highest output cost was found from $\mathrm{T}_{5}$ as 148421 Taka/ha which was statistically identical with other treatments except $\mathrm{T}_{1}(129261$ Taka/ha). High input cost is a major constrain of jute production (Sheheli and Roy, 2014). During the experiment it was observed that input cost increased with the increasing of fertilizer amount. At Table 4, it was found that the highest Benefit cost ratio was 2.33 from $\mathrm{T}_{5}$ followed by $T_{2}, T_{3}, T_{1}$ and $T_{4}$. But the differences of Benefit Cost Ratio (BCR) were not statistically significant. This result was also corroborated by Khanom et al. 2012; Haque et al., 2015 and Pervin et al., 2016. The fibre yield and BCR trend of jute with different fertilizer doses $\left(\mathrm{T}_{1}, \mathrm{~T}_{2}, \mathrm{~T}_{3}, \mathrm{~T}_{4}\right.$ and $\left.\mathrm{T}_{5}\right)$ at post harvest onion field are given at Fig 1.

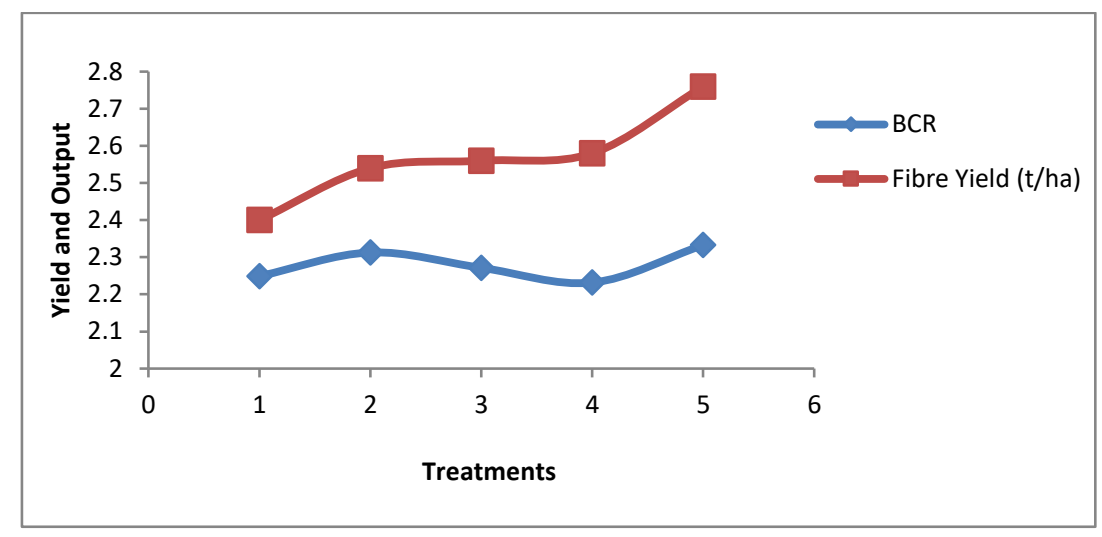

Fig. 1:Fibre Yield and BCR of Jute Cultivation with Different Treatments at Post Harvest Onion Field.

\section{Conclusion}

It was found that the fibre yield was significantly influenced by different doses of fertilizer during jute cultivation after harvesting of onion but the economic output was not significantly different for different fertilizer doses. The farmers may use $100 \%$ of recommended fertilizer dose for jute production to get maximum fiber yield but that yield expansion may not ensure to get maximum economic returns. So, it can be concluded that, in respect to economic output the farmers who cultivate jute after harvesting of onion can use no fertilizer for jute production. Further investigation is needed to establish such recommendation.

\section{References}

[1] Ali MS, Gani MN and Islam MM. 2017. Nutrient Management on Growth and Yield of BJRI Tossa Pat 6. Nutrition and Food Technology. 3(3): 15.https://doi.org/10.16966/2470-6086.147.

[2] District Statistics - 2011. Faridpur. 2013. Bangladesh Bureau of Statistics, Ministry of Planning, Government of the People's Republic of Bangladesh.

[3] FAO. 1988. Land Resources Appraisal of Bangladesh for Agricultural Development- Report 2: Agro-ecological regions of Bangladesh. Food and Agriculture Organization of the United Nations, Rome, Italy, 570p.

[4] Gani MN, Ali MS and Islam MM. 2018. Nutritional Requirements of Newly Released Tossa Jute MG-1. American Journal of Food, Nutrition and Health. 3(2): 31-34.

[5] Gomez AK and Gomez AA.1984. Statistical Procedure for Agric. Res. Int. Rice Res. Inst. Manila, Philippines. $2^{\text {nd }}$ Edi: 139-207.

[6] Haque SMA, Hossain I and Rahman MA. 2015. BCR for Seed and Fibre Production with Seed and Cutting Treatments at Different Sowing Methods at JAES and KRS, BJRI in O-9897 Variety. Universal Journal of Plant Science. 3(6): 141-147.

[7] Hvistendahl M. 2010. China's push to add by subtracting fertilizer. Science. 327(5967):801https://doi.org/10.1126/science.327.5967.801.

[8] Islam K and Silva HD. (2011). Jute Value Chain in Bangladesh: Information and Knowledge Gaps of Smallholders. www.lirneasia.net.

[9] Ju XT, Kou CL, Zhang FS and Christie P. 2006. Nitrogen balance and groundwater nitrate contamination: Comparison among three intensive cropping systems on the North China Plain. Environmental Pollution. 143: 117-125.https://doi.org/10.1016/j.envpol.2005.11.005.

[10] Khanom S, Hossain S and Hossain SA. 2012. Effects Of N, P, K and S Application on Yield and Quality of White Jute (Corchorus capsularis L.) Var. BJC-2197. Dhaka University Journal of Biological Science. 21(2): 109-116.https://doi.org/10.3329/dujbs.v21i2.11508.

[11] Molla MMU, Sabur SA and Begum IA. 2015. Financial and Economic Profitability of Jute in Bangladesh: A Comparative Assessment. The Journal of Agriculture and Natural Resources Sciences. 2(1): 295-303.

[12] Mostafizur ABM, Zaman MAU, Shahidullah SM and Nasim M. 2017. Diversity of Cropping Patterns and Land Use Practices in Faridpur Region. Bangladesh Rice Journal. 21 (2): 157-172.https://doi.org/10.3329/brj.v21i2.38203.

[13] Nasim M, Shahidullah SM, Saha A, Muttaleb MA, Aditya TL, Ali MA and Kabir MS. 2017. Distribution of Crops and Cropping Patterns in Bangladesh. Bangladesh Rice Journal. 21 (2): 1-55.https://doi.org/10.3329/brj.v21i2.38195.

[14] Pervin N, Parvin A, Sultana N and Kato K. 2016. Jute bioscience and cost-effective seed production trails. European Journal of Biotechnology and Bioscience. 4(8). 9-11.

[15] Sheheli S and Roy B. 2014. Constraints and opportunities of raw jute production: a household level analysis in Bangladesh. Progressive Agriculture. 25: 38-46.https://doi.org/10.3329/pa.v25i0.24070. 